\title{
EFFECT OF HYDROGEN SULFIDE-RELEASING ASPIRIN ON ESOPHAGEAL AND GASTRIC MUCOSA COMPROMISED BY STRESS INJURY
}

\author{
O. S. ZAYACHKIVSKA ${ }^{1}$, N. S. BULA', Ya. I. PAVLOVSKIY', I. O. PSHYK-TITKO', \\ E. M. GAVRILUK ${ }^{1}$, O. I. GRUSHKA ${ }^{1}$, J. L. WALLACE $E^{2,3}$ \\ ${ }^{1}$ Danylo Halytsky Lviv National Medical University, Ukraine; \\ ${ }^{2}$ University of Calgary, Canada; \\ ${ }^{3}$ University of Toronto, Canada; \\ e-mail: ozayachkivska@gmail.com
}

Recent data of study $\mathrm{H}_{2} \mathrm{~S}$ in gastrointestinal tract has proven its potent cytoprotection on mucosal defense among acid-related diseases in the gut. The aim was to evaluate the effects of $\mathrm{H}_{2} \mathrm{~S}$-releasing aspirin derivative (ATB-340) on esophageal and gastric mucosa compromised by stress injury. Rats were treated with vehicle (control), aspirin $(10 \mathrm{mg} / \mathrm{kg})$, ATB-340 $(17.5 \mathrm{mg} / \mathrm{kg})$ single or 9 days duration, with or without induction of stress injury. Esophageal mucosa, gastric mucosa were estimated by histopathological damage scoring. Serological levels of VCAM-1, IL-6 by ELISA. ATB-340 treatment resulted in protective effect and lower grade of damage score in esophageal mucosa and gastric mucosa lesions vs effect of aspirin in single or 9 days applications. The serum levels of VCAM, IL-6 in rats who were aspirin-treated and subjected to stressinjury were higher than those in control animals. Treatment with ATB-340 produced an anti-inflammatory effect by decreasing VCAM and IL-6 vs aspirin. Cytoprotective effect of ATB-340 on esophageal mucosa and gastric mucosa was modulated by inhibiting inflammation and improving endothelial functions.

Key words: $H_{2} S$, esophagus, stomach, aspirin, inflammation, cytoprotection, VCAM-1, IL-6.

$\mathrm{H}$ ydrogen sulfide $\left(\mathrm{H}_{2} \mathrm{~S}\right)$ is a crucial gaseous mediator of the regulation of vascular tone, blood flow, angiogenesis/granulation tissue (by angiogenic growth factors), inflammation, redox balance which is sufficient for healing gastrointestinal (GI) mucosa [1, 2]. More specifically, $\mathrm{H}_{2} \mathrm{~S}$, which easily diffuses through cell membranes, can lead to increased blood flow, mucus secretion, improvement of trophic processes, provision of cytoprotection, decrease leucocyte adhesion and facilitation of cellregeneration in GI organs [3, 4]. Thus, the functional effects of $\mathrm{H}_{2} \mathrm{~S}$ is very important in the prevention and treatment of GI mucosal damage.

The non-erosive diseases of upper part of the gastrointestinal (GI) tract, as esophagitis, Barrett esophagus or gastritis are the prevalent among acid-related diseases. Last data recognized them as disorders, which characterized by low-grade inflammation, which is, according to the WHO, is the background for several pre-malignant conditions, e.g., Barrett esophagus metaplasia for esophageal adenocarcinoma, ones of highest aggressive tumor with very poor prognosis [4]. Latest evidence-based data has shown the use of non-steroid anti-inflammatory drugs (NSAID), including aspirin, is implicate to cancer chemoprevention, including suppression of several pro-inflammatory pathways, as cyclooxygenase-2 (COX-2), tumor necrosis factor-alpha (TNF- $\alpha$ ), $\beta$-catenin nuclear translocation and mitogen-activated protein kinase signaling $[5,6]$.

Aspirin is one of the most common drugs used in the clinical practice, including cancer chemoprevention. The active substance of aspirin - acetylsalicylic acid (ASA) - was first synthesized from willow bark in 1899, although the knowledge of the anti-inflammatory effects of willow bark dates back to Hippocrates. ASA and other NSAIDs have also been highlighted for the cancer prevention, including esophageal adenocarcinoma [5, 7]. However, the significant negatives of such treatment include the undesirable side effects on GI organs, such as the development of acute erosive and ulcerative mucosal damage in the upper and lower parts of the GI tract, with subsequent induction of GI bleeding [8-10]. 
Moreover, last data has shown that these complications can develop in an achlorhydric environment $[8,11,12]$. Thus, the safer NSAIDs are crucial for medical practice and should based upon multidisciplinary studies of the role of sulfuric compounds in the maintenance of mucosal integrity [13].

Therefore, it is necessary to develop new safe drugs, which are based on stimulating physiological processes and promoting anti-inflammatory and anti-adhesive effects of $\mathrm{H}_{2} \mathrm{~S}$. The discovery of novel $\mathrm{H}_{2} \mathrm{~S}$-releasing NSAIDs by J. Wallace (from 2007 to present) demonstrated the beneficial effects of these drugs for a variety of disease-states; this may include dysbiosis, inflammatory periodontal damage, disorders of proliferation of the esophagus, duodenum, small and large intestine mucosa, motor disorders of the digestive system, $[3,13,14]$. It has been recently determined that acute GI cytoprotection is based on vasoprotection and maintenance of blood flow [15]. Stimulation of angiogenesis/granulation tissues by angiogenic factors, e.g. VEGF, bFGF, PDGF is sufficient for ulcer healing, so cytokines and interleukins play important roles in discovery endothelial function, and $\mathrm{H}_{2} \mathrm{~S}$ therapy seems to be also beneficial in enhancement for that [16]. The key markers of an injured endothelial state include the vascular cellular adhesion molecule-1 (VCAM), which is a proinflammatory cytokine that mediates the adhesion of lymphocytes, monocytes, eosinophils, and basophils to vascular endothelium [16], and interleukin-6 (IL-6), a protein secreted by $\mathrm{T}$ cells and macrophages that is a biomarker for several inflammatory signaling pathways [17]. Thus, based on these outcomes, we hypothesized that a novel $\mathrm{H} 2 \mathrm{~S}-$ releasing aspirin could be less harmful than classical pro-ulcer aspirin in induction GI mucosal damage (erosions, blood bleeding, ulcer), and in the same time it will keeping its beneficial effect for prevention low grade inflammation.

Therefore, the first aim of this study was to investigate the effects of aspirin and $\mathrm{H}_{2} \mathrm{~S}$-releasing aspirin (ATB-340, manufactured by Antibe Therapeutics Inc) on mucosal integrity in the esophagus and the stomach. The second aim was to explore and compare the effects of pre-treatment with aspirin or ATB-340 on acute esophageal and gastric lesions of rats induced by stress and the accompanying changes in the pre-epithelial, epithelial, and post-epithelial components of mucosal defense mechanisms, and to assess the release of VCAM and IL-6.

\section{Materials and Methods}

All experiments were carried out using male rats $(\mathrm{N}=66)$ weighing $180-220 \mathrm{~g}$, in accordance with the standards of the European Convention for the Protection of Vertebrate Animals Used for Experimental and Other Scientific Purposes (1986) and "Bioethical expertise of preclinical and other scientific researches conducted on animals" (Kyiv, 2006), and with permission from Committee on Bioethics of Lviv National Medical University (protocol No 5, 17.05.2014). Rats were maintained under a constant $12 \mathrm{~h}$ light/dark cycle and an ambient temperature of $21-23{ }^{\circ} \mathrm{C}$. All rats were fed a standard diet and were kept in raised mesh-bottom cages to prevent coprophagy. Rats were deprived of food for $18 \mathrm{~h}$ before the experiments with single administration of drugs and at the last day of experiments with chronic administration drugs, but had free access to water. Rats were anesthetized with an intraperitoneal injection of ketamine (60 mg/kg; Biovet, Ukraine). Six rats were used in each group.

This study was done in the two series of randomized study, in the first series the following treatments for rats was performed: 1 - intact animals were used as control (treated with single administration of the vehicle; $1.0 \mathrm{ml}$ saline), 2 and 3 - rats with a single oral administration of aspirin (CHFZ, Kyiv, Ukraine) at a dose $10 \mathrm{mg} / \mathrm{kg}$; or ATB-340 (4-(5-thioxo-5H-dithiol-3-yl) phenyl 2-acetoxybenzoate), a hydrogen sulfide-releasing derivative of aspirin (Antibe Therapeutics Inc; Fig. 1) at a dose $17.5 \mathrm{mg} / \mathrm{kg}$, equimolar to the dose of aspirin [18], respectively. To induce more severe acute damage in esophageal and gastric mucosa aspirin injury was combined with exposition to water immersion stress (WIS), as described by K. Takagi et al. [19], whereby rats were placed in restraint cages and immersed vertically to the level of the xiphoid process in a water bath of $23{ }^{\circ} \mathrm{C}$ for $3.5 \mathrm{~h}$. As a negative control, rats in 4 group - were pre-treated with a single administration of vehicle, while as a positive control, in 5 and 6 groups - they were treated with aspirin or ATB-340 in similar doses, respectively.

In the second series of experiments, the longterm effect of aspirin $(10 \mathrm{mg} / \mathrm{kg})$ and ATB-340 $(17.5 \mathrm{mg} / \mathrm{kg})$ over the course of 9 days on esophageal and gastric mucosal integrity was estimated in experimental groups 7 and 8 ; and with WIS induction in 9 - with vehicle pretreatment, in 10 - with aspirin pretreatment, and 11 - with ATB-340 pretreatment. 


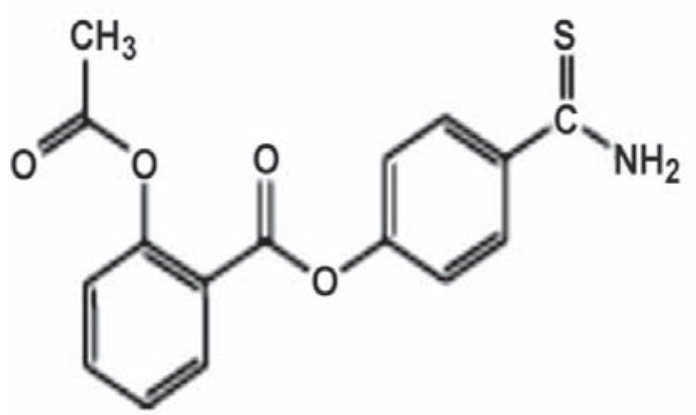

Fig. 1. Chemical structure of $\mathrm{H}_{2} \mathrm{~S}$-releasing aspirin (ATB-340) - 4-(5-thioxo-5H-dithiol-3-yl)phenyl2acetoxybenzoate

After euthanasia, the mucosal surface of the esophagus and the stomach was gently washed with phosphate-buffered (pH 7.4) saline. Gross appearance of esophageal and gastric mucosal integrity was graded via macroscopic investigation by two observers unaware of the treatment using the system described above, which takes into consideration the type, number and size of the lesions. Immediately after the termination of experiment, esophageal and gastric mucosal samples from the esophagus and the stomach, as well as from the esophagogastric junction, were collected for histopathological analysis. A sample of blood was drawn from the abdominal vein and placed in EDTA-containing vials and used for centrifugation, and plasma was collected for the future determination of the levels of pro-inflammatory mediators.

For evaluation of esophageal and gastric mucosa damage histological analysis was done with similar-sized samples. The mucosa from lower third of the esophagus were excised at the region $2 \mathrm{~mm}$ below the lower esophageal sphincter that separates forestomach from esophagus. The area of esophagogastric junction and serial sections obtained from stomach were also collected. Samples were fixed in $4 \%$ formalin and embedded in paraffin. Serial sections of 5- $\mu \mathrm{m}$ thickness were stained with hematoxylin/eosin. Sections were evaluated blindly by two individuals and their histology damage scores were averaged. To estimate the degree of mucosal lesions of esophagus and stomach, Leica DM 750/4 microscope and Leica DFC 420 digital photocamera, manufactured in Germany, were used. Videoanalysis of esophageal and gastric microsections was performed on, and licensed under, sLeica Application Suite video recording system, Version 3.8, manufac- tured in Germany, under x200 and x400 magnification lenses.

Evaluation of histological indexes of esophageal damage was blindly evaluated by two individuals and their scores based on EsoHisto, 2012 grading and focused on the loss of epithelium ( 0 - none, $1-$ minimal pre-ulcerative changes and splitting, 2 erosion formation or 3 -ulceration), vascular changes ( 0 - none, 1 - edema, 2 - submucosal vascular dilation, 3 - perivascular hemorrhage) and intraepithelial leukocyte infiltration ( 0 - none, 1 - mild, 2 moderate, 3 - severe) were averaged. Evaluation of histological indexes of gastric damage was based on mucosal epithelial cell damage $(0-$ none, 1 - impairment involving the glandular cells, 2 - mucosal erosion, 3 - bleeding or ulceration), vascular changes ( 0 - none, 1 - edema, 2 - submucosal vascular dilation, 3 - perivascular hemorrhage) and the degree of intraepithelial leukocyte infiltration $(0-$ none, $1-$ mild, 2 - moderate, 3 - severe) [20].

For determination of VCAM and IL-6 by ELISA blood samples were centrifuged at $3500 \mathrm{rpm}$ for 10 min at a temperature of $15^{\circ} \mathrm{C}$. Plasma was collected with a micropipette and stored in $-60{ }^{\circ} \mathrm{C}$ until ELISA assay was performed according to the manufacturer's instructions (Multi-Analyte ELISArray ${ }^{\circledR}$ Kit; Cedarlane, Canada). The intensity of color reaction was estimated using a GBG Stat-Fax 303 Plus Microstrip Reader (Shaker Stat-Fax 2200 Awareness Technology, Inc., Palm City, FL, USA) at $450 \mathrm{~nm}$ and 620-655 nm, respectively.

Statistical analysis. Data analysis was done by StatSoft, Inc. (2004) STATISTICA (data analysis software system), version 7. Results are presented as mean \pm standard deviation (SD). For comparison of all groups to control, the ANOVA and Dunnett's test was used. An associated probability of less than 5\% was considered significant.

\section{Results and Discussion}

It was shown that vehicle-treated rats exhibited normal esophageal and gastric gross appearance and with no histological signs of damage (Fig. 2, $A$ and Fig. 3, A). Treatment with aspirin, an inhibitor of COX synthesis, resulted in hyperemia in the lower third of esophagus and single erosions in gastric mucosa (Fig. 2, $B$ and Fig. 3, B). The degree of gross appearance of damage of esophageal mucosa in rats that received ATB-340 after WIS induction manifested itself with hyperemia, and histologically with ASA-induced esophagitis with alteration of 
the corneal layer, loss of keratin, epithelial splitting and desquamation of the lumen and thickened subepithelial part of the esophagus (Fig. 2, C). Gross appearance of gastric mucosa in rats from this group was characterized by hemorrhagic erosions, which were frequently located on rests of gastric rugal folds in contrast to vehicle-treated rats. The 9 days administration of aspirin at a dose of $10 \mathrm{mg} / \mathrm{kg}$ per day caused erosions on the lower third of esophageal mucosa and multiple erosions and ulcers in gastric mucosa as compared to normal esophageal and gastric surface without detectable mucosal damage in vehicle-treated rats. The ASA-associated lesions of the esophagus were characterized by sub-epithelial vascular changes such as edema, submucosal vascu-

A

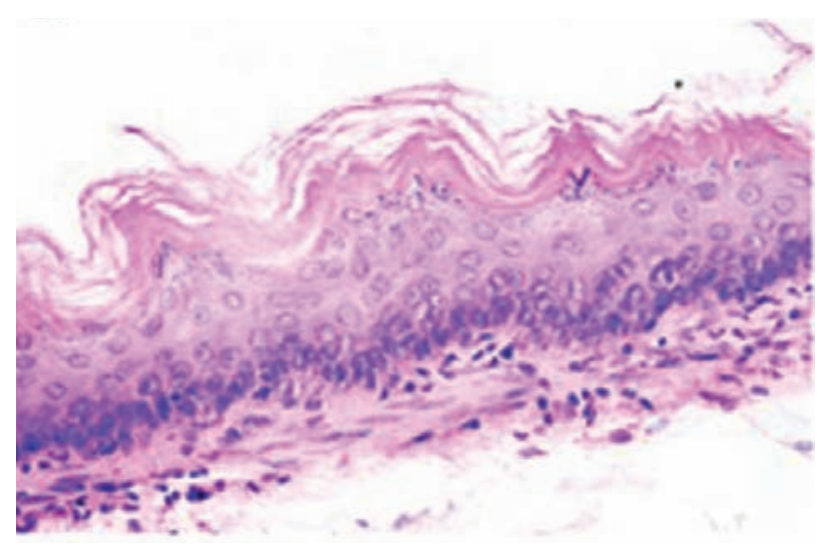

C

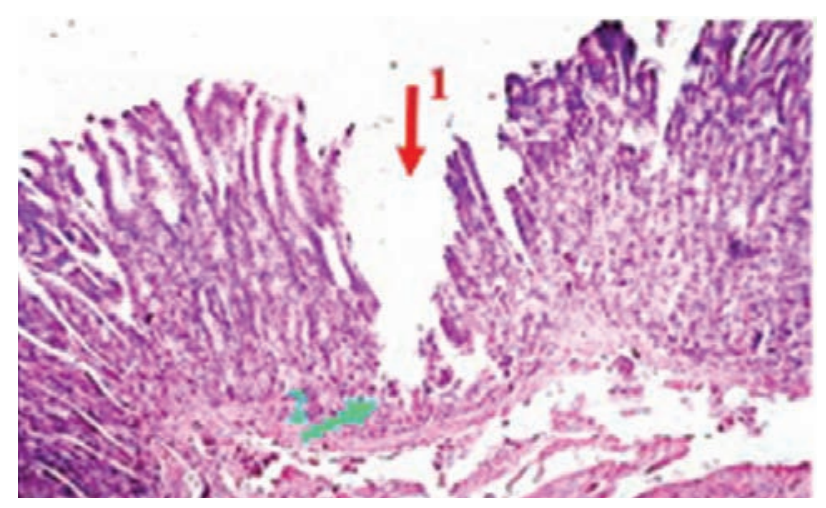

lar dilation, perivascular hemorrhage, and perivascular diapedesis combined with elevated intraepithelial leukocyte infiltration. Oral administration of ATB-340 to rats over 9 days with induction of WIS produced hyperemia in the middle part of esophagus and manifested itself histologically through submucosal vascular dilation and minor leukocyte infiltration in the esophageal mucosa (Fig. 2, D). The development of acute gastric lesions in these rats was characterized by damage of mucosal epithelial and glandular cells, mucosal erosions, and sub-epithelial infiltrates (Fig. 3, F, E). The severity of esophageal and gastric mucosa estimated by damage score indexes from rats of all groups has shown that ATB340 reduced stress-injury dramatically in both single

B

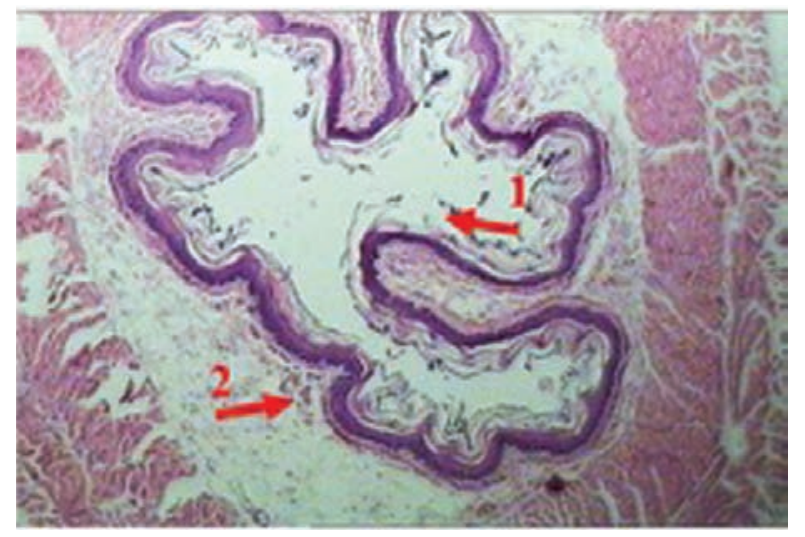

D

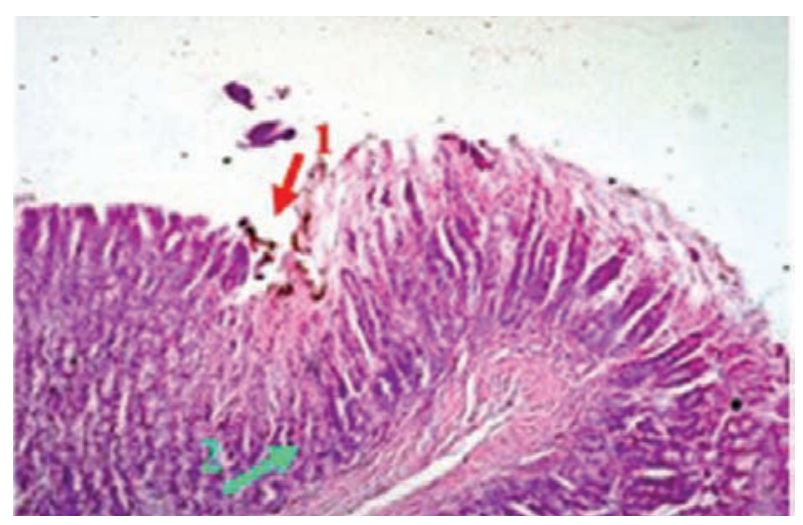

Fig. 2. Changes of esophageal and gastric mucosa in rats without and with induction water-immersion stress and treatment of ATB-340; hematoxylin and eosin staining, panels: A 4400 and B x400; $C$ and D x100. Panel A shows normal mucosa from vehicle-treated control. Panel $B$ - pre-ulcerative changes in cross-section of esophageal mucosa, compromised by stress (splitting superficial keratin ( $\uparrow 1$ ) and irregular sub-epithelial edema ( $\uparrow 2)$. Panel C displays effect of single treatment of ATB in the dose $17.5 \mathrm{mg} / \mathrm{kg}$ on gastric mucosa compromised by stress with focal epithelial lesions ( $\uparrow 1$ ) and leukocyte infiltration of basal layer of gastric mucosa ( $\uparrow 2)$. Panel D illustrates effects of 9 days ATB treatment with $17.5 \mathrm{mg} / \mathrm{kg}$ per day on gastric mucosa compromised by stress with mild epithelial lost ( $\uparrow 1)$ and minor sub-epithelial infiltrate ( $\uparrow 2)$ 
A

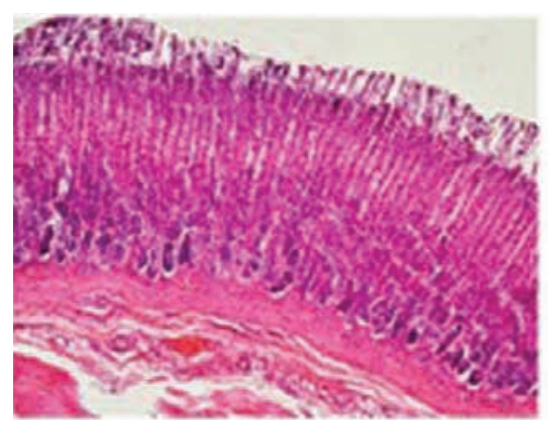

B

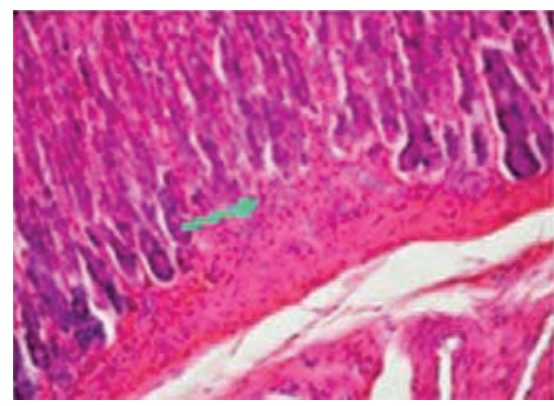

C

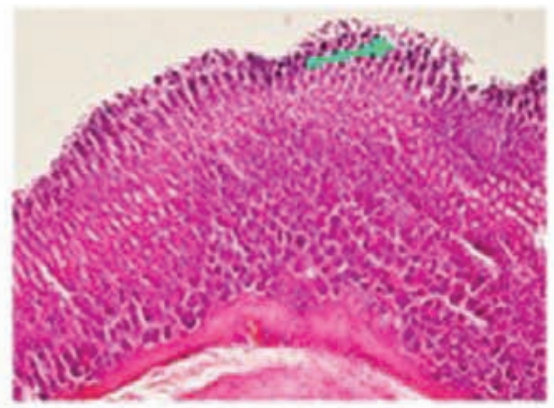

D

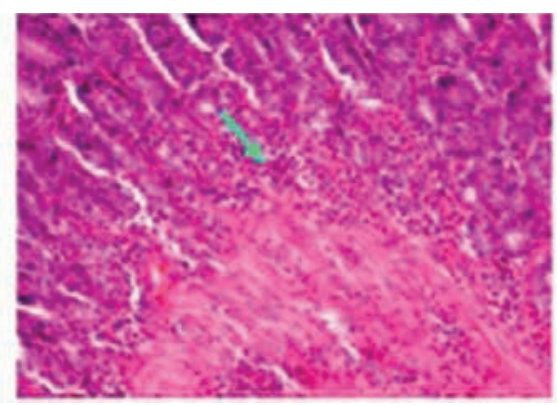

E

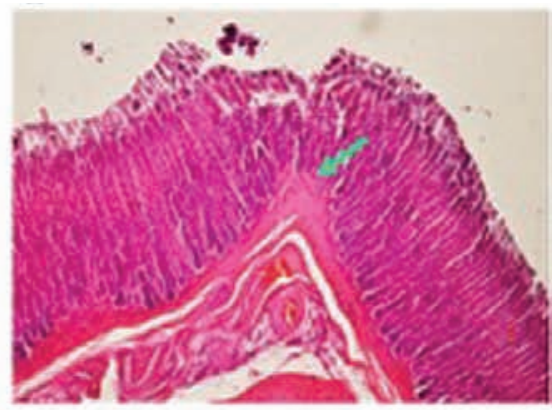

F

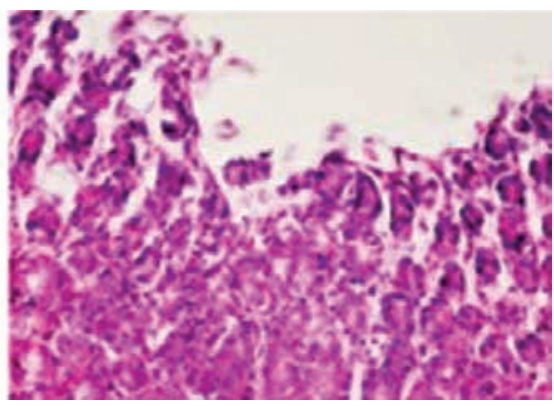

Fig. 3. Effects of ATB-340 treatment (17.5 mg/kg) on gastric mucosa without and with signs of stress-induced injury, hematoxylin and eosin staining; panels: A, C and Ex100; B, D and F x400. Panel A shows normal gastric mucosa from vehicle-treated rat; solid arrows on panel $B$ illustrates minor subepithelial infiltrate from rat after single treatment of ATB; on panels $C$ and D shows the effect of single administration of ATB on mucosa, compromised by stress (C-minimal pre-ulcerative changes and splitting superficial epithelium; D - focal epithelial lesions and leukocyte infiltration of basal layer); on panels $E$ and $F$ displays the effect of 9-days treatment of ATB (E-focal epithelial lesions and leukocyte infiltration of basal layer; $F$ - minor infiltrate of lamina propria)

and 9-days administration in comparison to similar with aspirin treatment (Fig. 4).

In the present study was shown that ATB-340 modulates synthesis of endothelium-derived VCAM and inflammation. Fig. 5 demonstrates the realization of VCAM and IL-6 in vehicle-treated rats in control group and in that treated with a single and 9-days administration of aspirin, H2S-aspirin (ATB-340) without and with exposition to WIS. Administration of ATB-340 was accompanied by a significant sharply decrease of serum level of VCAM in both cases without and with WIS induction $(P<0.05)$, as compared to those treated by saline (Fig. 5, A). During investigation an effect of ATB-340 treatment on IL-6 serum level in rats with single treatment of ATB-340 without and with stress compromising (Fig. 5, B) it was recognized a 2-times fall of IL-6 level in comparison to those treated by aspirin $(P<0.05)$.

The long-term effect of 9-days administration of ATB-340 or aspirin on serum level of VCAM in rats compromised by WIS induction (Fig. 5, C) was resulted in a significant fall of VCAM levels in the case of $\mathrm{H}_{2} \mathrm{~S}$-aspirin treatment opposite to the effect of classical aspirin $(P<0.05)$. Compound ATB340 over the 9-days administration (Fig. 5, D) led to significant suppression of endogenous synthesis of IL-6 serum in comparison as those were during aspirin treatment when it induced pro-inflammatory effect $(P<0.001)$. During WIS induction in rats with 9-days ATB-340 treatment, which spontaneously releases H2S, IL-6 serum level was decreased in $30 \%$ to those observed during aspirin administration $(P \leq 0.05)$. Recent data have shown that aspirin is among the most commonly prescribed NSAIDs for several diseases, including the prevention of malignancy in gut, as well as pre-eclampsia, cognitive decline, systemic inflammatory response syndrome, and its continuous use often causes adverse effects on GI organs. Changes in serum cytokines in this study correspondent to severity of esophagitis 
$A$

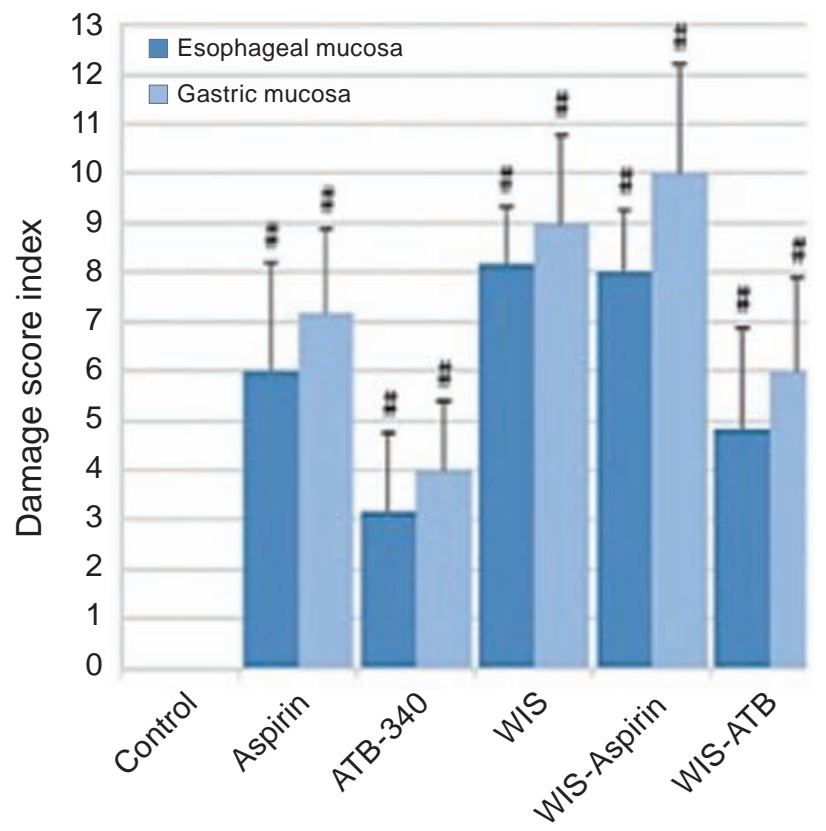

B

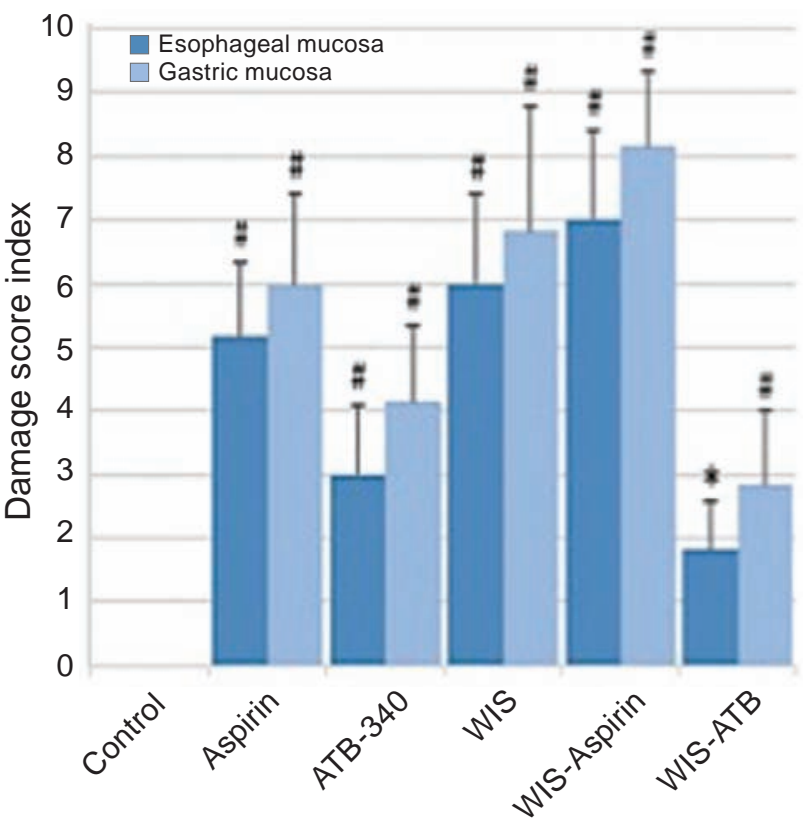

Fig. 4. The histological damage score indexes of esophageal and gastric injury during administration aspirin and $\mathrm{H}_{2} \mathrm{~S}$-releasing aspirin (ATB-340) in rats subjected to water-immerssion stress. $* P<0.05$; $\# P<0.01$ corresponded to control (vehicle-treated rats; one-way ANOVA and Dunnett's test). Data are presented as mean and standard deviation $(n=6$ per group)

and gastritis induced by aspirin administration. At the same time, endothelial dysfunction is a crucial pathophysiological mechanism for ulcerogenesis in esophagus and stomach, and introduction of effective therapy for endothelial cells, as well as maintenance of mucosal blood flow as the main target and mechanism of esophago- and gastroprotective drugs, is urgently needed. Among numerous factors which affect vascular permeability (prostaglandins, nitric oxide, carbon monooxyde, toxic chemicals, chemokines and cytokines), $\mathrm{H}_{2} \mathrm{~S}$ is now considered to play a key role in endothelial permeability, promotion of anti-inflammatory and antioxidant activities $[2,11]$. Previous studies have shown that the leukocyte-endothelium interface is critical in pathogenesis of NSAID-induced mucosal injury, and this interaction is a rational target for therapies aimed at preventing this form of injury [19]. In the present study, ATB-340 has shown significant cytoprotective effects on esophageal and gastric mucosa as compared to single or long-term (9 days) administration of aspirin. In order to verify vasoprotective properties of ATB-340, we also used the induction of stress, which is a universally accepted standard used for compromising gut mucosa and simulating gastric and esophageal damage. Our findings were confirmed ATB-340 esophagoprotective and gastroprotective effects by the results of histopathological analysis, which employed standards of ranking gastric and esophageal damage, as well as through the investigation of VCAM and IL- 6 cytokines. Obtained evidence of decreased VCAM and IL-6 serum levels confirms ATB-340 protective effect on endothelium, the latter governing the leading cytoprotection mechanism in esophagus and stomach. This verifies the substance's inability to form erosions and ulcers on esophageal and gastric mucosa is related with $\mathrm{H}_{2} \mathrm{~S}$ effective influence and it confirms that $\mathrm{H}_{2} \mathrm{~S}$-releasing aspirin are safe to upper part of digestive system and during stress compromising.

We conclude that ATB-340 is a novel protective substance with esophagoprotective and gastroprotective effects which are attributable to effects of role of $\mathrm{H}_{2} \mathrm{~S}$ on vascular permeability and mucosal defence in GI tract. This novel modification of $\mathrm{H}_{2} \mathrm{~S}$-aspirin contributes significantly on regulation esophageal and gastric mucosal defence, and inflammation mediated by reduction of VCAM and IL- 6 synthesis, and it may be promising for the development pharmacological drug in future. 

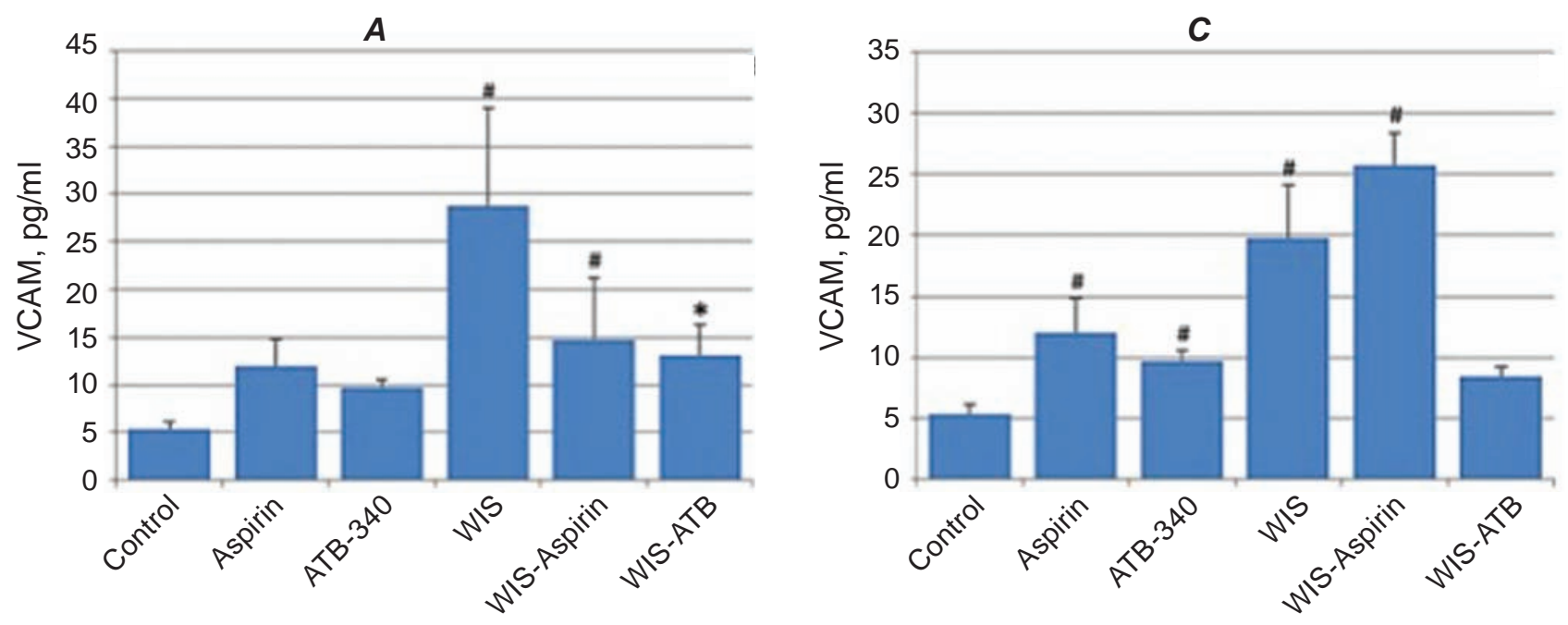

B
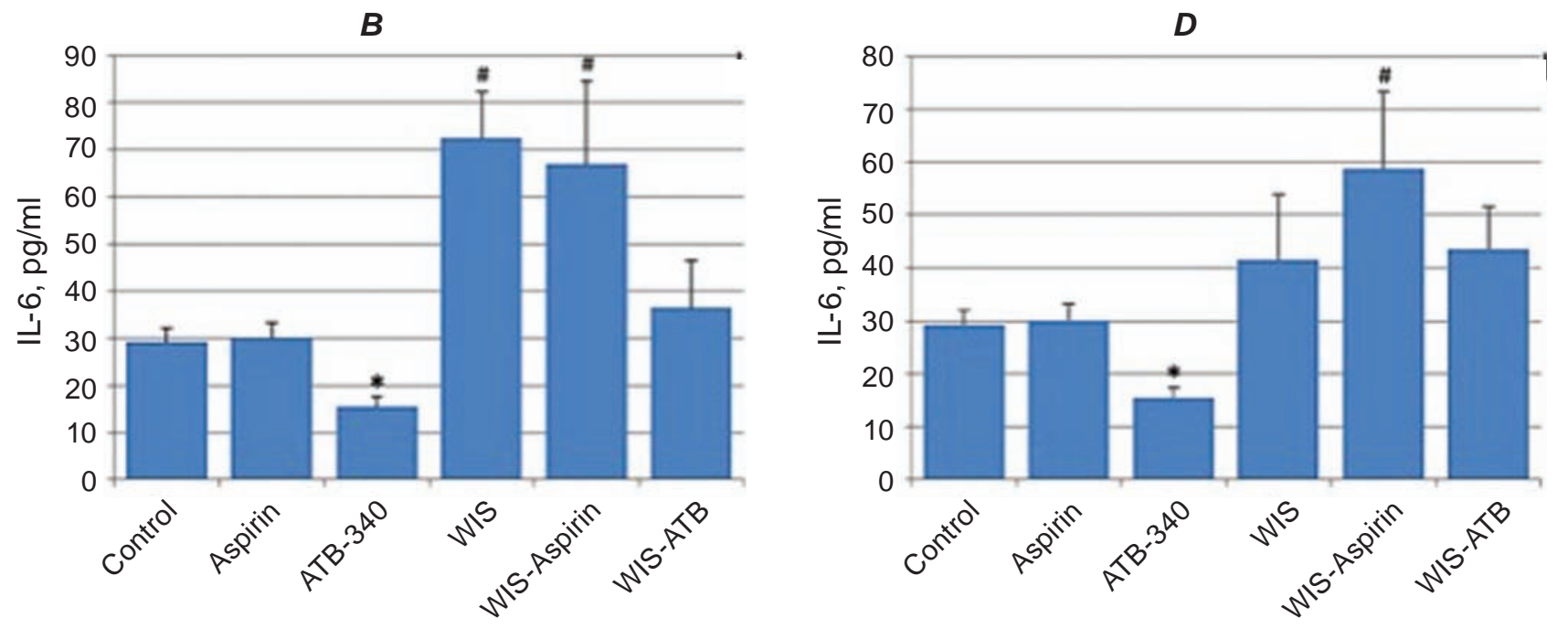

Fig. 5. Determination of serum concentrations of VCAM (pg/ml) and IL-6 (pg/ml) by ELISA in rats treated with single (panels $A, B)$ amd 9 days (panels $C, D)$ oral administration of vehicle (control), aspirin (10.0 mg/ $\mathrm{kg}$ ) or ATB-340 (17.5 mg/kg), without or with exposure to water-immersion stress. $* P<0.05$; \#P $<0.01$ corresponded to control (vehicle-treated rats; one-way ANOVA and Dunnett's test). Data are presented as mean and standard deviation ( $n=6$ per group)

\section{Acknowledgments}

We thank Cedars Sinai Medical Center's International Research and Innovation in Medicine Program, the Association for Regional Cooperation in the Fields of Health, Science and Technology (RECOOP HST Association) for their support of our organization as participating Cedars - Sinai Medical Center - RECOOP Research Centers (CRRC).
The authors are grateful to Antibe Therapeutics Inc (Canada) for providing the ATB-340 and ELISA kits for VCAM and IL-6 (Cedarlane, Canada), and to Prof. Yurij Bisyarin (Bioptat Ltd., Lviv) for helping optimize and perform the histological analysis. Dr. Wallace's research is supported by a grant from the Canadian Institutes of Health Research. 


\section{ЕФЕКТ ГІДРОГЕН-СУЛЬФІД- СПОРІДНЕНОГО АСПІРИНУ НА УШКОДЖЕНУ СТРЕСОМ СЛИЗОВУ ОБОЛОНКУ СТРАВОХОДУ ТА ШЛУНКУ}

О. С. Заячківська ${ }^{1}$, Н. С. Була ${ }^{1}$, Я. I. Павловський', I. О. Пиик-Тітко О. М. Гаврилюк', О. І. Грушка ${ }^{1}$ Дю. Л. Уоллас ${ }^{2,3}$

\author{
${ }^{1}$ Львівський національний медичний університет \\ імені Данила Галицького, Україна; \\ ${ }^{2}$ Університет Калгарі, Канада; \\ ${ }^{3}$ Університет Торонто, Канада; \\ e-mail: ozayachkivska@gmail.com
}

Останні дані про вплив гідроген-сульфіду $\left(\mathrm{H}_{2} \mathrm{~S}\right)$ на органи травлення свідчать щодо його потужної цитопротекторної дії на слизову оболонку. Метою дослідження було оцінити вплив $\mathrm{H}_{2} \mathrm{~S}$-спорідненого аспірину (ATB-340) на ушкоджену стресом слизову оболонку стравоходу та шлунку щурів. Щурам вводили плацебо (контроль), аспірин (10 мг/кг) та АТВ-340 (17,5 мг/ кг) разово та упродовж 9 днів, із індукцією стресу та без нього. За допомогою гістологічного аналізу оцінювали пошкодження слизової оболонки стравоходу та шлунку. Серологічний вміст VCAM-1 та IL-6 вивчали імуноензимним аналізом. Застосування АТВ-340 виявило зменшення гістологічного індексу ушкодження слизової оболонки стравоходу та шлунку (у порівнянні з даними у разі введення аспірину) як під час разового, так і 9-денного введення. Серологічний рівень VCAM i IL-6 у щурів, яким вводили аспірин та індукували стрес, був вищий, ніж у контрольних тварин. Введення щурам АТВ-340 спричинювало протизапальний ефект шляхом зменшення вмісту VCAM та IL-6, чого не спостерігалося при застосуванні аспірину. Таким чином, за введення АТВ-340 спостерігали зменшення запалення та покращення функціонування ендотелію судин у слизовій оболонці стравоходу та шлунку щурів.

Ключ чов і слова: $\mathrm{H}_{2} \mathrm{~S}, \quad$ стравохід, шлунок, аспірин, запалення, цитопротекція, VCAM-1, IL-6.

\section{ЭФФЕКТ ГИДРОГЕН-СУЛЬФИД- АССОЦИИРОВАННОГО АСПИРИНА НА ПОВРЕЖДЕННУЮ СТРЕССОМ СЛИЗИСТУЮ ОБОЛОЧКУ ПИЩЕВОДА И ЖЕЛУДКА}

\author{
О. С. Заячковская ${ }^{1}$ Н. С. Була \\ Я. И. Павловский \\ О. М. Гаврилюк ${ }^{1}$ О. И. Грушка \\ Дж. Л. Уоллас ${ }^{2,3}$
}

\author{
${ }^{1}$ Львовский национальный медицинский \\ университет имени Данила Галицкого, Украина; \\ ${ }^{2}$ Университет Калгари, Канада; \\ ${ }^{3}$ Университет Торонто, Канада; \\ e-mail: ozayachkivska@gmail.com
}

Последние данные о влиянии гидрогенсульфида $\left(\mathrm{H}_{2} \mathrm{~S}\right)$ на пищеварительную систему доказывают его мощное цитопротекторное влияние на слизистую оболочку. Целью исследования было оценить влияние $\mathrm{H}_{2} \mathrm{~S}$ ассоциированного аспирина (АТВ-340) на поврежденную стрессом слизистую оболочку пищевода и желудка крыс. Крысам вводили плацебо (контроль), аспирин (10 мг/кг) и АТВ340 (17,5 мг/кг) разово и в течение 9 дней, с индукцией стресса и без него. С помощью гистологического анализа оценивали повреждение слизистой оболочки пищевода и желудка. Серологические уровни VCAM-1 и IL-6 оценивали имунноэнзимным анализом. Применение АТВ340 вызывало уменьшение индекса повреждения слизистой оболочки пищевода и желудка (по сравнению с применением аспирина) как при разовом, так и при 9-дневном введении. Серологический уровень VCAM и IL-6 у крыс, которым вводили аспирин и индуцировали стресс, был выше, чем у контрольных животных. Введените крысам АТВ-340 приводило к противовоспалительному эффекту за счет снижения уровни VCAM и IL-6 по сравнению с группой, которой вводили аспирин. Таким образом, при введении АТВ-340 наблюдали снижение воспаления и улучшение функционирования эндотелия сосудов слизистой оболочки пищевода и желудка крыс.

К л ю че вы е с лова: $\mathrm{H}_{2} \mathrm{~S}$, пищевод, желудок, аспирин, воспаление, цитопротекция, VCAM-1, IL-6. 


\section{References}

1. Kimura H, Shibuya N, Kimura Y. Hydrogen sulfide is a signaling molecule and a cytoprotectant. Antioxid Redox Signal. 2012; 17(1): 45-57.

2. Zaichko NV, Melnik AV, Yoltukhivskyy MM, Olhovskiy AS, Palamarchuk IV. Hydrogen sulfide: metabolism, biological and medical role. Ukr Biochem J. 2014; 86(5): 5-25.

3. Chan MV, Wallace JL. Hydrogen sulfide-based therapeutics and gastrointestinal diseases: translating physiology to treatments. Am $J$ Physiol Gastrointest Liver Physiol. 2013; 305(7): G467- G473.

4. Jankowski J, Bennett C, Jankowski JA. Management of Barrett esophagus: a practical guide for clinicians based on the BADCAT and BoB CAT recommendations. Pol Arch Med Wewn. 2015; 125(10): 765-770.

5. Sadeghi S, Bain CJ, Pandeya N, Webb PM, Green AC, Whiteman DC; Australian Cancer Study. Aspirin, nonsteroidal anti-inflammatory drugs, and the risks of cancers of the esophagus. Cancer Epidemiol Biomarkers Prev. 2008; 17(5): 1169-1178.

6. Nguyen DM, Richardson P, El-Serag HB. Medications (NSAIDs, statins, proton pump inhibitors) and the risk of esophageal adenocarcinoma in patients with Barrett's esophagus. Gastroenterology. 2010; 138(7): 2260-2266.

7. Peura DA, Wilcox CM. Aspirin and proton pump inhibitor combination therapy for prevention of cardiovascular disease and Barrett's esophagus. Postgrad Med. 2014; 126(1): 87-96.

8. Sostres C, Lanas A. Gastrointestinal effects of aspirin. Nat Rev Gastroenterol Hepatol. 2011; 8(7): 385-394.

9. Higgs GA, Salmon JA, Henderson B, Vane JR. Pharmacokinetics of aspirin and salicylate in relation to inhibition of arachidonate cyclooxygenase and antiinflammatory activity. Proc Natl Acad Sci USA. 1987; 84(5): 1417-1420.

10. Vane JR. Biomedicine. Back to an aspirin a day? Science. 2002; 296(5567): 474-475.
11. Goldstein JL, Cryer B. Gastrointestinal injury associated with NSAID use: a case study and review of risk factors and preventative strategies. Drug Healthc Patient Saf. 2015; 7: 31-41.

12. Freedberg DE, Lebwohl B, Abrams JA. The impact of proton pump inhibitors on the human gastrointestinal microbiome. Clin Lab Med. 2014; 34(4): 771-785.

13. Blackler RW, Gemici B, Manko A, Wallace JL. NSAID-gastroenteropathy: new aspects of pathogenesis and prevention. Curr Opin Pharmacol. 2014; 19: 11-16.

14. Wallace JL, Blackler RW, Chan MV, Da Silva GJ, Elsheikh W, Flannigan KL, Gamaniek I, Manko A, Wang L, Motta JP, Buret AG. Antiinflammatory and cytoprotective actions of hydrogen sulfide: translation to therapeutics. Antioxid Redox Signal. 2015; 22(5): 398-410.

15. Papapetropoulos A, Pyriochou A, Altaany Z, Yang G, Marazioti A, Zhou Z, Jeschke MG, Branski LK, Herndon DN, Wang R, Szabó C. Hydrogen sulfide is an endogenous stimulator of angiogenesis. Proc Natl Acad Sci USA. 2009; 106(51): 21972-21977.

16. Schlesinger M, Bendas G. Vascular cell adhesion molecule-1 (VCAM-1)-an increasing insight into its role in tumorigenicity and metastasis. Int J Cancer. 2015; 136(11): 2504-2514.

17. Mihara M, Hashizume M, Yoshida H, Suzuki M, Shiina M. IL-6/IL-6 receptor system and its role in physiological and pathological conditions. Clin Sci (Lond). 2012; 122(4): 143-159.

18. Wallace J., Pshyk-Titko I., Marcelo N. Muscara, et al. Influence of Hydrogen Sulfide-releasing aspirin on mucosal integrity of oesophageal and gastric mucosa. Proc Shev Sci Soc.: Med. 2015; XLIII: 63-74.

19. Takagi K, Kasuya Y, Watanabe K. Studies on the drugs for peptic ulcer. A reliable method for producing stress ulcer in rats. Chem Pharm Bull (Tokyo). 1964; 12: 465-472.

20. Szabo S, HollanderD. Pathways of gastrointestinal protection and repair: mechanisms of action of sucralfate. Am J Med. 1989; 86(6A): 23-31.

Received 31.01.2017 